\title{
Impact of mechanical ventilation on quality of life and functional status after ICU discharge: A cross-sectional study
}

\author{
Patrini Silveira Vesz ${ }^{1}$, Rafael Viegas Cremonese ${ }^{2}$, Regis Goulart Rosa ${ }^{3}$, Juçara Gasparetto Maccari ${ }^{3}$, Cassiano Teixeira** (i) \\ ${ }^{1}$ PT, McS, Universidade Federal de Ciências da Saúde de Porto Alegre (UFCSPA), Rehabilitation Sciences Graduate, Porto Alegre, RS, Brazil \\ ${ }^{2} \mathrm{MD}$, Department of Critical Care, Hospital Ernesto Dornelles, Porto Alegre, RS, Brazil \\ ${ }^{3} \mathrm{MD}, \mathrm{PhD}$, Department of Critical Care, Hospital Moinhos de Vento, Porto Alegre, RS, Brazil \\ ${ }^{4} \mathrm{MD}$, PhD, UFCSPA, Rehabilitation Sciences Graduate, and Department of Critical Care, Hospital Moinhos de Vento, Porto Alegre, RS, Brazil
}

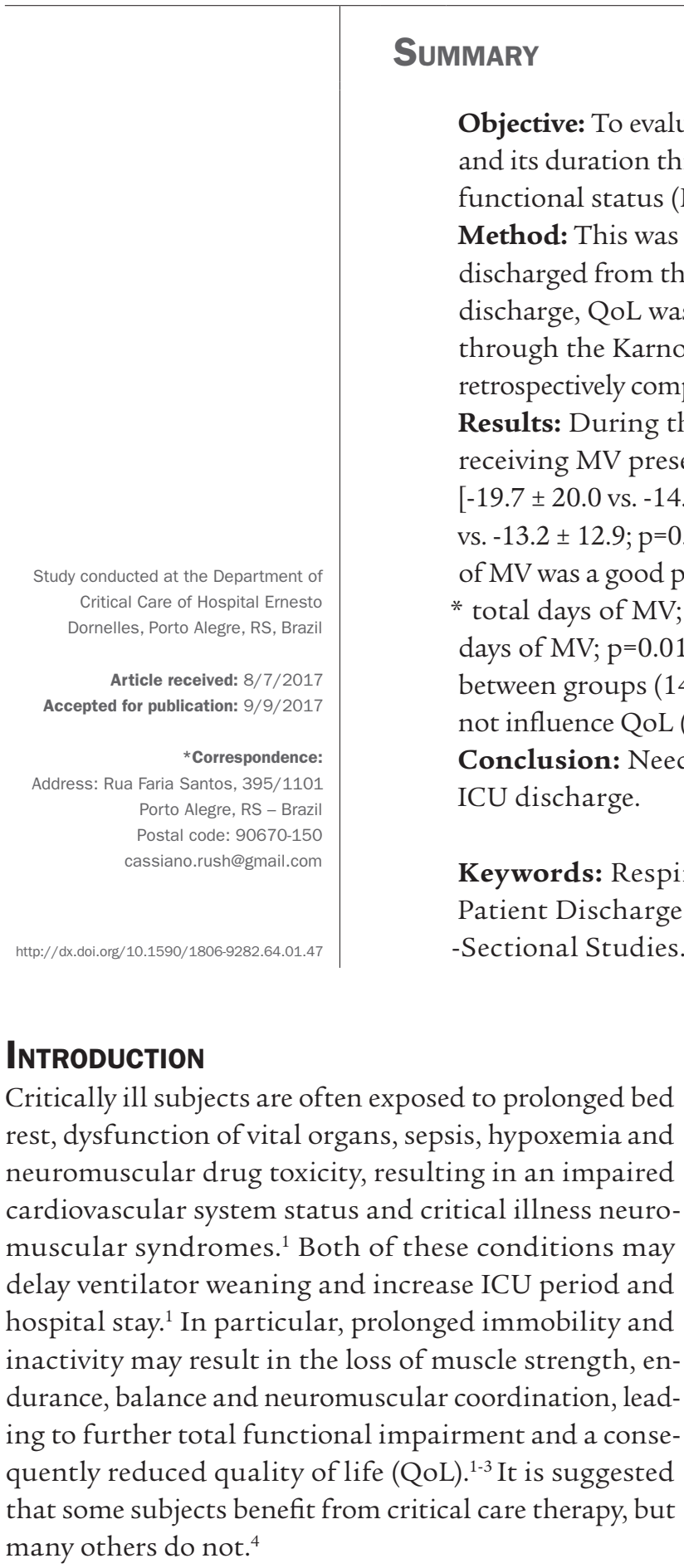

Mechanical ventilation (MV) is the highest priority indicator for admission to ICUs, according to accepted guidelines. ${ }^{5}$ Subjects who require MV are usually the most severe ones. In addition, increasing numbers of these patients generate particular controversy regarding their uncertain long-term outcomes and disability. The greater is the duration of MV, the worse the prognosis appears to be. ${ }^{6-8}$ Some authors described that MV subjects experience poor survival, low QoL, reduced physical functional status (PFS) and poor cognitive functioning; the subjects also require substantial post-discharge care. Other authors demonstrated a survival benefit with MV. ${ }^{7}$

A clearer description of the outcomes of MV subjects post-discharge can be observed in clinical decision-mak- 
ing, institutional planning, payment reform and design of future interventions targeted to these unique subjects. ${ }^{6,9}$ There are no studies establishing the relation of PFS and QoL with MV dependency. Therefore, the objective of our study was to verify the impact of MV (need and duration) on QoL and PFS of subjects after immediate ICU discharge.

\section{Method}

\section{Design and participants}

The present investigation was a cross-sectional study that included all the subjects admitted to and discharged from the ICU of the Ernesto Dornelles Hospital (a 22-bed clinical-surgical ICU) during a 1-year period (from August 2012 to August 2013). Patients < 18 years of age, those who remained in the ICU for $<72 \mathrm{~h}$, those subjected to elective surgery without clinical or surgical complications and those who refused to sign the informed consent were excluded from our study. Eligible subjects who were readmitted to the ICU during the study period were only included once. The study was approved by the research ethics committee of the Federal University of Health Sciences of Porto Alegre (no. 332.519) and consisted of a preliminary analysis of an ongoing multicenter cohort that is expected to include 1,500 participants.

\section{Intervention}

Each eligible patient, or a close relative, was requested to sign the informed consent form during the first week following discharge from the ICU. The subjects who agreed to participate were subjected to an interview with physical therapists and psychologists previously trained to apply the following questionnaires and scales to assess the participants' current condition: PFS (modified-Barthel index and Karnofsky performance status) and QoL (WHOQoL-Bref). The PFS was also assessed in the period prior to ICU admission, retrospectively. The Portuguese translations of all these scales have already been validated. ${ }^{10-12}$

\section{Physical-functional status evaluation}

The modified-Barthel index objectively assesses the degree of dependence of individuals relative to 10 categories of activities of daily living (ADLs): personal hygiene, bathing, feeding, toilet use, climbing stairs, dressing, bladder and anal sphincter function, walking, and transfer from bed to chair. ${ }^{13,14}$ The score ranges from 0 to 100 and is interpreted as follows: 0-20, totally dependent; 21-60, severely dependent; 61-90, moderately dependent; 91-99, slightly dependent; and 100, totally independent. ${ }^{13,15,16}$ The questionnaire can be answered by the subjects, their relatives, or their caregivers. For the present analysis, the absolute values (from 1, totally dependent, to 5 , totally independent) of each domain were used.

The Karnofsky Performance Status assesses the degree of functional impairment. It was initially designed to assess the physical performance of subjects with cancer, but its use was extended to other chronic disabling diseases. ${ }^{14}$ Based on their scores, the individuals were classified as follows: 100, normal, having no complaints and no evidence of disease; 90 , capable of normal activity and with few symptoms of disease; 80 , normal activity with some difficulty and some symptoms of disease; 70 , capable of self-care and not capable of normal activity or work; 60 , occasionally requires some assistance but can take care of most personal needs; 50 , requires considerable assistance or frequent medical care; 40 , disabled and requires special care and assistance; 30 , severely disabled, with indicated hospital admission, although death is not imminent; 20, very ill, requiring hospital admission; and 10, moribund, with fatal process progressing rapidly. ${ }^{11}$

\section{Quality of life evaluation}

Data on QoL were collected using the World Health Organization Quality of Life Bref-Scale (WHOQoL-Bref). The WHOQoL-Bref is a shorter version of the original WHOQoL-100 and consists of 26 items that are scored over four major domains, namely physical, psychological, social relationships, and environment. ${ }^{12,17-19}$ The responses of the WHOQoL-Bref are scored in a Likert-type scale yielding 1 to 5 points, with higher scores denoting higher QoL and vice-versa. ${ }^{18,20}$

\section{Outcome measures}

The information relative to the participants, ICU stay was collected from their clinical records including the following data: demography, severity scores, reason for ICU admission, diseases before ICU admission, requirement for life support (e.g., invasive or non-invasive MV hemodialysis; vasopressors such as dopamine, noradrenaline and dobutamine; or blood-component transfusions such as red-blood-cell concentrates, plasma, and platelets) and ICU outcomes.

\section{Data analyses}

The data are expressed as mean \pm standard deviation (SD) or absolute and relative frequencies. The Kolmogorov-Smirnov test was used to investigate the normal distribution of the data. The categorical variables were analyzed using Fisher's exact test, and the quantitative 
variables were analyzed using Wilcoxon-Mann-Whitney test. The comparison between the differences in score variation [score post-ICU immediate discharge (score before ICU admission $[\Delta]$ ) in the Karnofsky Performance Status and modified-Barthel index scales and the average WHOQoL-Bref scores between subjects who required MV and those who did not were performed using the Wilcoxon-Mann-Whitney test. Linear regression was conducted to assess the impact of the length of MV on QoL scores. The significance level was established as $\mathrm{p}<0.05$. The analysis was performed using Stata software version 12 (Stata Corp LP, USA).

\section{Results}

During the study period, 160 subjects discharged from the ICU were included in the analyses. The data corresponding to the participants' ICU stay are described in Table 1 , and the following results stood out: subjects with MV were younger $(69.5 \pm 15.3$ years vs. $73.8 \pm 14.9$ years; $\mathrm{p}=0.04)$ and had a higher ICU stay length $(8.9 \pm 5.4$ vs. $5.8 \pm 3.0$ days, $\mathrm{p}<0.001)$.

The results from the modified-Barthel index indicated a tendency of higher difference in score variation of subjects with MV dependence compared with those of subjects without $\mathrm{MV}(\Delta=-17.4 \pm 12.8$ vs. $-13.2 \pm 12.9$; $\mathrm{p}=0.05)$. Furthermore, the Karnofsky Performance Status revealed a poorer functional capacity of subjects with MV after immediate ICU discharge $(\Delta=-19.7 \pm 20.0$ vs.
$-14.9 \pm 18.2 ; p=0.04)$. However, the WHOQoL-Bref scores showed no difference between groups $(14.0 \pm 1.8$ vs. $14.5 \pm 1.9 ; \mathrm{p}=0.14)$.

Table 2 describes the individual variation of each ADLs category in the modified-Barthel index. The comparison of the categories before and after ICU showed that the group of subjects with MV had a poorer performance in dressing and climbing stairs. Table 2 also describes the WHOQoL-Bref domains, which showed no difference between groups.

The duration of MV was a good predictor of PFS impairment in the immediate ICU discharge (Figures 1A and 1B), but not of QoL (Figure 1C).

\section{Discussion}

The main finding of the present study is that MV during ICU stay is an indicator of poor physical functional capacity immediately after ICU discharge.

Impairment has been reported in the ADLs of almost all ICU survivors in studies that evaluated subjects immediately after ICU discharge. ${ }^{21-23}$ Nevertheless, the literature is controversial regarding the association between PFS and the MV need. Some authors suggested that functional status during post-hospital follow-up does not seem to be influenced by the use of MV. ${ }^{24}$ Other study reported that ICU survivors have a reduced functional capacity in ADLs immediately after ICU discharge, and these limitations are associated with the duration of

TABLE 1 Characteristics of the participants.

\begin{tabular}{llll} 
Variables & Subjects with $\mathbf{M V}(\mathbf{n = 1 0 7})$ & Subjects without $\mathbf{M V}(\mathbf{n = 5 3 )}$ & $\mathbf{P}$ \\
\hline Male gender, $\mathrm{n}(\%)$ & $64(59.8)$ & $28(52.8)$ & 0.49 \\
\hline Age (years), mean $\pm \mathrm{SD}$ & $69.5 \pm 15.3$ & $73.8 \pm 14.9$ & 0.04 \\
\hline Body mass index $\left(\mathrm{kg} / \mathrm{m}^{2}\right)$, mean $\pm \mathrm{SD}$ & $26.5 \pm 5.9$ & $27.0 \pm 7.2$ & 0.71 \\
\hline Previous diseases, $\mathrm{n}(\%)$ & & & $10(18.8)$ \\
$\quad$ Heart failure & $17(15.8)$ & $4(7.5)$ & 0.65 \\
Ischemic heart disease & $6(5.6)$ & $13(24.5)$ & 0.73 \\
Diabetes mellitus & $20(18.6)$ & $3(5.6)$ & 0.41 \\
Peripheral artery disease & $5(4.6)$ & $0(0)$ & 0.71 \\
End-stage chronic kidney failure & $5(4.6)$ & $8(15.0)$ & 0.17 \\
Cerebrovascular disease & $16(14.8)$ & $5(9.4)$ & 0.99 \\
Dementia & $10(9.3)$ & $5(9.4)$ & 0.99 \\
Bronchial asthma & $3(2.8)$ & $11(20.7)$ & 0.11 \\
Chronic obstructive pulmonary disease & $15(14.0)$ & $3(5.6)$ & 0.36 \\
Depression & $7(6.5)$ & $18.0 \pm 6.0$ & 0.99 \\
\hline APACHE-II, mean \pm SD & $20.1 \pm 7.9$ & $5.8 \pm 3.0$ & 0.08 \\
\hline ICU length of stay (days), mean \pm SD & $8.9 \pm 5.4$ & $<0.001$ \\
\hline
\end{tabular}

MV: mechanical ventilation; SD: standard deviation; APACHE-II: Acute Physiology and Chronic Health Evaluation II; ICU: intensive care unit.

Note: Difference between qualitative variables evaluated by Fisher's exact test. Difference between quantitative variables evaluated by the Wilcoxon-Mann-Whitney test. 
TABLE 2 Comparison $^{+}$of the score variation* in categories of modified-Barthel index and comparison ${ }^{+}$of the WHOQoL-Bref domains between critically ill subjects receiving or not mechanical ventilation.

\begin{tabular}{|c|c|c|c|}
\hline Barthel's categories & Subjects with MV ( $n=107)$ & Subjects without MV $(n=53)$ & $\mathbf{p}$ \\
\hline Feeding & $-1.58 \pm 1.38$ & $-1.24 \pm 1.43$ & 0.10 \\
\hline Bathing & $-1.71 \pm 1.30$ & $-1.32 \pm 1.42$ & 0.05 \\
\hline Dressing & $-1.82 \pm 1.63$ & $-1.22 \pm 1.58$ & 0.04 \\
\hline Personal hygiene & $-2.09 \pm 1.66$ & $-1.69 \pm 1.61$ & 0.13 \\
\hline Anal sphincter function & $-1.91 \pm 1.62$ & $-1.47 \pm 1.51$ & 0.09 \\
\hline Bladder function & $-1.44 \pm 1.46$ & $-1.00 \pm 1.37$ & 0.06 \\
\hline Toilet use & $-1.46 \pm 1.76$ & $-1.05 \pm 1.59$ & 0.17 \\
\hline Transfer from bed to chair & $-1.36 \pm 1.65$ & $-1.13 \pm 1.72$ & 0.28 \\
\hline Walking & $-2.0 \pm 1.64$ & $-1.54 \pm 1.55$ & 0.08 \\
\hline Climbing stairs & $-1.84 \pm 1.47$ & $-1.26 \pm 1.44$ & 0.01 \\
\hline WHOQoL-Bref domains & Subjects with MV $(n=60)$ & Subjects without MV $(n=34)$ & $\mathbf{p}$ \\
\hline Physical & $11.7 \pm 3.1$ & $12.3 \pm 2.1$ & 0.48 \\
\hline Psychological & $14.8 \pm 2.1$ & $14.8 \pm 2.5$ & 0.92 \\
\hline Social relationships & $15.9 \pm 2.6$ & $17.0 \pm 1.9$ & 0.07 \\
\hline Environment & $14.9 \pm 2.2$ & $14.4 \pm 2.5$ & 0.29 \\
\hline
\end{tabular}

MV: mechanical ventilation. Variables expressed as mean \pm standard deviation.

+ Wilcoxon-Mann-Whitney test.

* Score variation = score post-ICU immediate discharge - score before ICU admission.

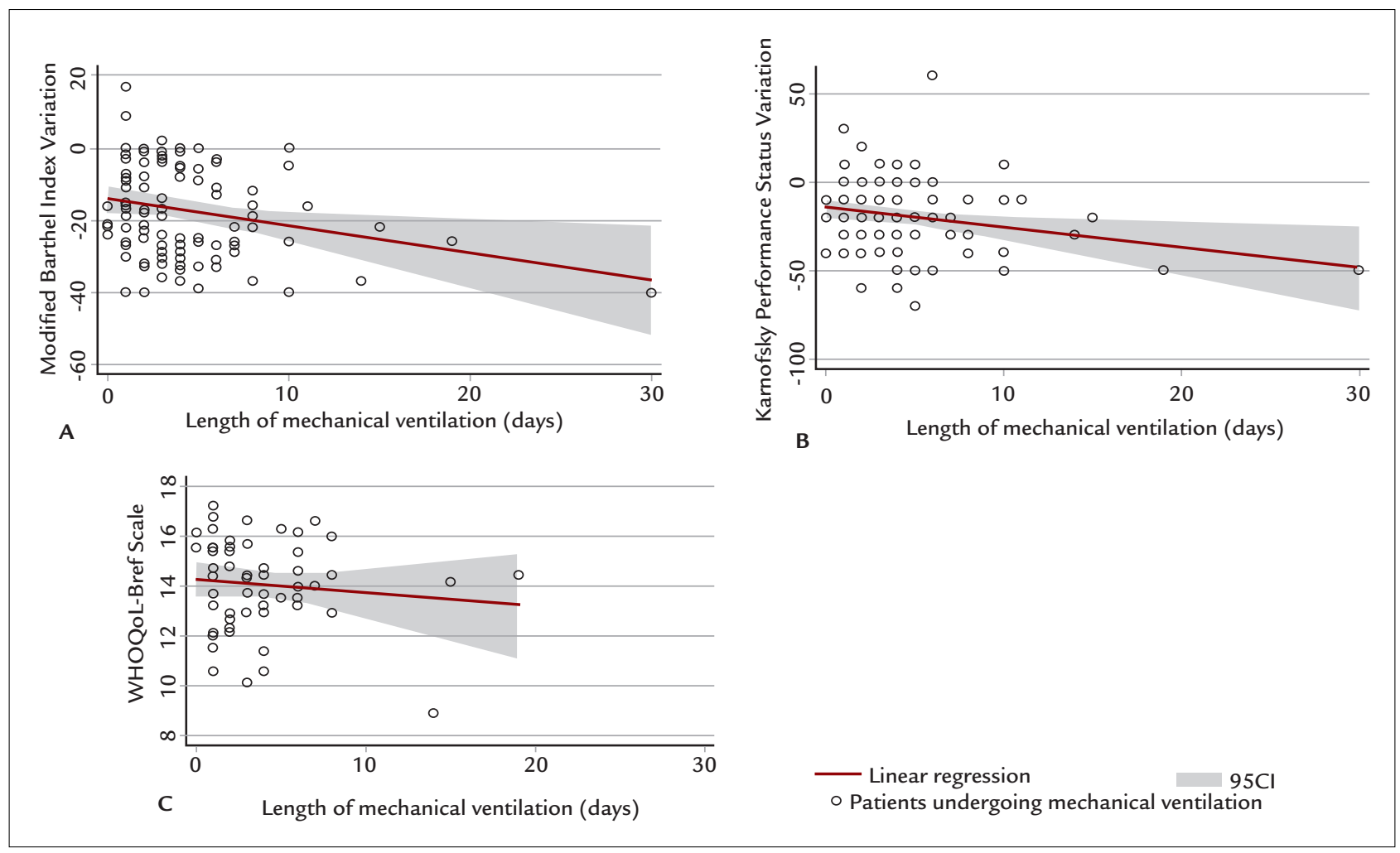

FIGURE 1 A. Linear regression between duration of mechanical ventilation and the score variation of modified-Barthel index+. B. Linear regression between duration of mechanical ventilation and the score variation of Karnofsky Performance Status++. C. Linear regression between duration of mechanical ventilation and WHOQoL-Bref scale+++.

Note: ${ }^{+}$Score variation $=$score post-ICU immediate discharge - score before ICU admission. Score variation of modified-Barthel index $=-14.2-0.74 *$ total days of MV; $\mathrm{p}=0.01 .{ }^{++}$Score variation $=$ score post-ICU immediate discharge - score before ICU admission. Score variation of Karnofsky performance status $=-14.6-1.12^{*}$ total days of $\mathrm{MV} ; \mathrm{p}=0.01 .{ }^{+++} \mathrm{WHOQ}$ oL-Bref scale $=14.2-0.05^{*}$ total days of MV; $p=0.43$. 
$M V .{ }^{25}$ A previous study by our group demonstrated that the use of $M V \geq 8$ days reduced the ability to perform ADLs by 1.48 times $(\mathrm{RR}=1.48$; 95CI 1.02-2.15; $\mathrm{p}=0.03) .{ }^{10}$ ADLs impairments may be more prevalent in MV subjects because $86 \%$ of subjects ventilated for $\geq 48 \mathrm{~h}$ had limitations in physical function, and approximately $75 \%$ of these limitations were severe by the $12^{\text {th }}$ month after discharge. ${ }^{26}$ Our study also demonstrated the loss of PFS associated with the use of MV. We believe that because $\mathrm{MV}$ is used in more severe cases, which require longer ICU stay, these patients are more often exposed to hypoxemia, bed immobility, use of sedatives and risk of nosocomial infections (not measured by us). The use of $\mathrm{MV}$ is not complication-free, affecting the patient as a whole by impairing their physical condition and thus worsening their functional capacity.

Most subjects using MV for longer periods and who survive one year report significant deficits in physical functioning, energy, and sleep. More specifically, measures of functional status were significantly worse in MV subjects, especially for subscales which measured mobility, body care, and movement. ${ }^{9}$ Walking ability and upper-extremity grip strength were identified as independent-explanatory consequences of poorer PFS. ${ }^{25}$ In another study, the authors demonstrated that more than $25 \%$ of subjects report restrictions in activities related to walking such as walking slowly and having problems with walking stairs, hills, and distances. ${ }^{14}$ These results corroborate ours, in which subjects of the MV group also showed deficit in climbing stairs and dressing.

Studies assessing QoL after intensive care suggest that this parameter improves over time, but is worse than that before the ICU admission, and worse than expected for the general population. ${ }^{27-31}$ The association between QoL and MV remains unclear. Subjects using long-term MV had consistently worse overall QoL than short-term subjects, but the differences were not statistically significant. ${ }^{9}$ Another study that compared long-term and shortterm MV found that, in the analysis of the physical domain, the long-term MV group showed worse results, specifically in mobility and body care. ${ }^{32} \mathrm{~A} 3$-year followup study showed that subjects that used MV for > 14 days, and another study with subjects who remained in the ICU for $>24 \mathrm{~h}$, found no correlation between the duration of MV with overall QoL. ${ }^{33,34}$ Some authors described that intubation was not significantly associated with either physical or mental domain scores one month after ICU discharge. ${ }^{35}$ In our study, MV showed no association with QoL at immediate ICU discharge. Most of our subjects underwent short-term MV, which may have influenced our results. It is also known that subjects who are in sta- ble conditions after ICU stay may be more likely to express positive perceptions in their QoL than subjects with unstable disease. ${ }^{19}$ It is important to note that $\mathrm{QoL}$ is a dynamic and variable phenomenon across different subjects and presents time variation for the same patient. ${ }^{36}$ In any case, the ideal time to evaluate QoL has not yet been established. ${ }^{30,35,37,38}$ Although many of the subjects reported a decline in functional status and many other symptoms, they were satisfied with their QoL. The majority of survivors described their health as good or better and would opt for MV support again if they had to relive the experience. ${ }^{38}$ However, it is unknown if family members think the same way. ${ }^{39}$

The immediate post-discharge period remains an important target for improving outcomes and disease management models and should be further evaluated. ${ }^{9}$ It is believed that the care provided in ICU settings and the assessment of the interventions performed should be determined earlier along the interval between discharge from the ICU and discharge from the hospital. These measures would have a long-term impact on the QoL of critically ill subjects. ${ }^{40}$ Although it is known that no single variable such as the use of MV has a significant and accurate prognosis, it may have implications for patient care, family planning and decision-making. ${ }^{32}$ The simple health grouping model outcomes we reported may help in this regard.

Concerning the limitations of our study, we should first mention the selected assessment method (i.e., the use of questionnaires). Although this technique is not subjective, it depends on the individuals' reading and understanding skills, their honesty and their hearing capacity during the interviews; also, the questionnaires may present measurement bias. Moreover, a memory bias should be considered if the questionnaires included information regarding the patient's conditions before ICU admission. In this context, it is noteworthy that survivors of severe diseases might overestimate their state before admission, as reported by other authors. ${ }^{38,39}$ The large number of subjects excluded should be addressed, which led to a small sample that may not be representative, especially because few of the study's subjects used MV for more than 10 days. Furthermore, our study was conducted in a single center, as a preliminary analysis of an ongoing multicenter cohort.

\section{Quick LOOK}

Mechanical ventilation is an indicator of poor physical functional capacity after ICU discharge.

Mechanical ventilation can decrease the quality of life after ICU discharge. 
Duration of mechanical ventilation decreases the physical functional status after ICU discharge.

\section{Conflict of Interest}

The authors declare no conflict of interest.

\section{Resumo}

Impacto da ventilação mecânica na qualidade de vida e no estado funcional após alta da UTI: um estudo transversal

Objetivo: Avaliar o impacto da necessidade de ventilação mecânica (VM) e sua duração na qualidade de vida (QV) e no estado funcional físico (EFF) dos pacientes após a alta imediata da UTI.

Método: Estudo transversal incluindo todos os pacientes que, consecutivamente, tiveram alta da UTI durante um período de um ano. Durante a primeira semana após a alta da UTI, a QV foi avaliada através do questionário WHOQoL-Bref e o EFF através do índice de Karnofsky e do índice de Barthel modificado, comparados retrospectivamente com o estado pré-admissão (variação $[\Delta]$ dos índices).

Resultados: Durante o estudo, 160 indivíduos preencheram os critérios de inclusão. Os indivíduos submetidos a VM apresentaram maior prejuízo no EFF ( $\Delta$ Karnofsky $[-19,7 \pm 20,0$ vs. $-14,9 \pm 18,2 ; \mathrm{p}=0,04]$ e $\Delta$ Barthel modificado $[-17,4 \pm 12,8$ vs. $-13,2 \pm 12,9 ; \mathrm{p}=0,05])$ quando comparados aos pacientes sem VM. A duração da VM foi um bom preditor de redução do EFF ( $\triangle$ Karnofsky [-14,6-1,12 * dias totais de VM; $\mathrm{p}=0,01]$ e $\Delta$ Barthel modificado [-14,2-0,74 * dias totais de VM; $\mathrm{p}=0,01]$ ). A QV, avaliada pelo WHOQoL-Bref, não mostrou diferença entre os grupos $(14,0 \pm 1,8$ vs. $14,5 \pm 1,9 ; \mathrm{p}=0,14)$ e a duração da VM não influenciou a QV (WHOQoL-Bref [14,2-0,05* dias totais de VM; $\mathrm{p}=0,43]$ ).

Conclusão: A necessidade e a duração do VM reduzem a performance física dos pacientes após a alta da UTI.

Palavras-chave: Respiração Artificial. Qualidade de Vida. Unidades de Terapia Intensiva. Alta do Paciente. Atividades Cotidianas. Recuperação de Função Fisiológica. Estudos Transversais.

\section{References}

1. Jones C. Recovery post ICU. Intensive Crit Care Nurs. 2014; 30(5):239-45

2. Christakou A, Papadopoulos E, Patsaki I, Sidiras G, Nanas S. Functional assessment scales in a general intensive care unit. A review. Hosp Chronicles. 2013; 8:164-70.

3. Aitken LM, Burmeister E, McKinley S, Alison J, King M, Leslie G, et al. Physical recovery in intensive care unit survivors: a cohort analysis. Am J Crit Care. 2015; 24(1):33-40

4. Carson SS, Bach PB, Brzozowski L, Leff A. Outcomes after long-term acute care. An analysis of 133 mechanically ventilated patients. Am J Respir Crit Care Med. 1999; 159(5 Pt 1):1568-73.
5. Lieberman D, Nachshon L, Miloslavsky O, Dvorkin V, Shimoni A, Zelinger $\mathrm{J}$, et al. Elderly patients undergoing mechanical ventilation in and out of intensive care units: a comparative, prospective study of 579 ventilations. Crit Care. 2010; 14(2):R48.

6. Unroe M, Kahn JM, Carson SS, Govert JA, Martinu T, Sathy SJ, et al. One-year trajectories of care and resource utilization for recipients of prolonged mechanical ventilation: a cohort study. Ann Intern Med. 2010; 153(3):167-75.

7. Cox CE, Carson SS, Lindquist JH, Olsen MK, Govert JA, Chelluri L; Quality of Life After Mechanical Ventilation in the Aged (QOL-MV) Investigators. Differences in one-year health outcomes and resource utilization by definition of prolonged mechanical ventilation: a prospective cohort study. Crit Care. 2007; 11(1):R9

8. Mafra JMS. Avaliação da qualidade de vida e funcionalidade do paciente crítico após alta hospitalar [dissertation]. São Paulo: Faculdade de Medicina da Universidade de São Paulo; 2012.

9. Carson SS. Outcomes of prolonged mechanical ventilation. Curr Opin Crit Care. 2006; 12(5):405-11.

10. Haas JS, Teixeira C, Cabral CR, Fleig AH, Freitas AP, Treptow EC, et al. Factors influencing physical functional status in intensive care unit survivors two years after discharge. BMC Anesthesiol. 2013; 13:11.

11. Leitão AVA, Castro CLN, Basile TM, Souza THS, Braulio VB. Evaluation of the nutritional status and physical performance in candidates to liver transplantation. Rev Assoc Med Bras. 2003; 49(4):424-8.

12. Fleck MPA, Louzada S, Xavier M, Chachamovich E, Vieira G, Santos L, et al Aplicação da versão em português do instrumento abreviado de avaliação da qualidade de vida "WHOQOL-bref". Rev Saude Publica. 2000; 34(2):178-83.

13. Graciani $Z$. Caracterização motora e funcional da paraplegia espástica, atrofia óptica e neuropatia periférica (síndrome Spoan) [dissertation]. São Paulo: Faculdade de Medicina da Universidade de São Paulo; 2009.

14. Hayes JA, Rowan KM, Black NA, Jenkinson C, Young JD, Daly K, et al. Outcome measures for adult critical care: a systematic review. Health Technol Assess. 2000; 4(24):1-111.

15. Bennett $M$, Ryall $N$. Using the modified Barthel index to estimate survival in cancer patients in hospice: observational study. BMJ. 2000; 321(7273):1381-2.

16. Tomasović Mrčela N, Massari D, Vlak T. Functional independence, diagnostic groups, hospital stay, and modality of payment in three Croatian seaside inpatient rehabilitation centers. Croat Med J. 2010; 51(6):534-42.

17. Kluthcovsky ACGC, Kluthcovsky FA. O WHOQOL-bref, um instrumento para avaliar qualidade de vida: uma revisão sistemática. Rev Psiquiatr Rio Gd Sul. 2009; 31(3 Suppl. 0).

18. Naumann VJ, Byrne GJ. WHOQOL-BREF as a measure of quality of life in older patients with depression. Int Psychogeriatr. 2004; 16(2):159-73.

19. Tabah A, Philippart F, Timsit JF, Willems V, Français A, Leplège A, et al. Quality of life in patients aged 80 or over after ICU discharge. Crit Care. 2010; 14(1):R2.

20. Chiu WT, Huang SJ, Hwang HF, Tsauo JY, Chen CF, Tsai SH, et al. Use of the WHOQOL-BREF for evaluating persons with traumatic brain injury. J Neurotrauma. 2006; 23(11):1609-20.

21. Douglas SL, Daly BJ, Kelley CG, O’Toole E, Montenegro H. Chronically critically ill patients: health-related quality of life and resource use after a disease management intervention. Am J Crit Care. 2007; 16(5):447-57.

22. Loss SH, Oliveira RP, Maccari JG, Savi A, Boniatti MM, Hetzel MP, et al. The reality of patients requiring prolonged mechanical ventilation: a multicenter study. Rev Bras Ter Intensiva. 2015; 27(1):26-35.

23. Needham DM, Davidson J, Cohen H, Hopkins RO, Weinert C, Wunsch H, et al. Improving long-term outcomes after discharge from intensive care unit: report from a stakeholders' conference. Crit Care Med. 2012; 40(2):502-9.

24. Sacanella E, Pérez-Castejón JM, Nicolás JM, Masanés F, Navarro M, Castro $\mathrm{P}$, et al. Functional status and quality of life 12 months after discharge from a medical ICU in healthy elderly subjects: a prospective observational study. Crit Care. 2011; 15(2):R105

25. van der Schaaf M, Dettling DS, Beelen A, Lucas C, Dongelmans DA, Nollet F. Poor functional status immediately after discharge from an intensive care unit. Disabil Rehabil. 2008; 30(23):1812-8.

26. Desai SV, Law TJ, Needham DM. Long-term complications of critical care. Crit Care Med. 2011;39(2):371-9.

27. Griffiths JA, Morgan K, Barber VS, Young JD. Study protocol: the Intensive Care Outcome Network ('ICON') study. BMC Health Serv Res. 2008; 8:132.

28. Cuthbertson BH, Scott J, Strachan M, Kilonzo M, Vale L. Quality of life before and after intensive care. Anaesthesia. 2005; 60(4):332-9.

29. Klimašauskas A, Sereikè I, Klimašauskienė A, Kèkštas G, Ivaškevičius J. The impact of medical conditions on the quality of life of survivors at discharge from intensive care unit. Medicina (Kaunas). 2011; 47(5):270-7. 
30. Fildissis G, Zidianakis V, Tsigou E, Koulenti D, Katostaras T, Economou A, et al. Quality of life outcome of critical care survivors eighteen months after discharge from intensive care. Croat Med J. 2007; 48(6):814-21.

31. Dowdy DW, Eid MP, Sedrakyan A, Mendez-Tellez PA, Pronovost PJ, Herridge MS, et al. Quality of life in adult survivors of critical illness: a systematic review of the literature. Intensive Care Med. 2005; 31(5):611-20.

32. Douglas SL, Daly BJ, Gordon N, Brennan PF. Survival and quality of life: shortterm versus long-term ventilator subjects. Crit Care Med. 2002; 30(12):2655-62.

33. Combes A, Costa MA, Trouillet JL, Baudot J, Mokhtari M, Gibert C, et al. Morbidity, mortality, and quality-of-life outcomes of subjects requiring >or=14 days of mechanical ventilation. Crit Care Med. 2003; 31(5):1373-81.

34. Orwelius L, Nordlund A, Nordlund P, Simonsson E, Bäckman C, Samuelsson A, et al. Pre-existing disease: the most important factor for health related quality of life long-term after critical illness: a prospective, longitudinal, multicentre trial. Crit Care. 2010; 14(2):R67.

35. Vest MT, Murphy TE, Araujo KL, Pisani MA. Disability in activities of daily living, depression, and quality of life among older medical ICU survivors: a prospective cohort study. Health Qual Life Outcomes. 2011; 9:9.
36. Azoulay E, Kentish-Barnes N, Pochard F. Health-related quality of life: an outcome variable in critical care survivors. Chest. 2008; 133(2):339-41.

37. Hofhuis JG, Spronk PE, van Stel HF, Schrijvers GJ, Rommes JH, Bakker J. The impact of critical illness on perceived health-related quality of life during ICU treatment, hospital stay, and after hospital discharge: a long-term follow-up study. Chest. 2008; 133(2):377-85.

38. Oeyen SG, Vandijck DM, Benoit DD, Annemans L, Decruyenaere JM. Quality of life after intensive care: a systematic review of the literature. Crit Care Med. 2010; 38(12):2386-400.

39. Chelluri L, Im KA, Belle SH, Schulz R, Rotondi AJ, Donahoe MP, et al. Longterm mortality and quality of life after prolonged mechanical ventilation. Crit Care Med. 2004; 32(1):61-9.

40. Vesz PS, Costanzi M, Stolnik D, Dietrich C, de Freitas KL, Silva LA, et al. Functional and psychological features immediately after discharge from an intensive care unit: prospective cohort study. Rev Bras Ter Intensiva. 2013; 25(3):218-24. 